\begin{tabular}{lc}
\hline & ANNALES \\
& UNIVERSITATIS MARIAE CURIE-SKŁODOWSKA \\
LOL. V & SECTIO N \\
\hline
\end{tabular}

ISSN: 2451-0491 • e-ISSN: 2543-9340 - CC-BY 4.0 • DOI: 10.17951/en.2020.5.343-357

\title{
Exploring Intercultural Differences between East and West throughout Cultural Dimensions and Literature
}

\author{
Badanie różnic międzykulturowych między Wschodem \\ a Zachodem poprzez wymiary kulturowe i literaturę
}

\author{
Ivana Pondelíková (Styková) \\ Matej Bel University in Banská Bystrica. \\ Department of European Cultural Studies \\ Tajovského 40, 97401 Banská Bystrica, Slovakia \\ ivana.stykova@umb.sk \\ http://orcid.org/0000-0003-4557-0616
}

\begin{abstract}
Abstrakt. W artykule opisano różnice międzykulturowe między Wschodem i Zachodem w wymiarze kulturowym oraz w literaturze. Istniejące badania socjologiczne są uzupełniane badaniami literackimi, co stanowi nowoczesny sposób prowadzenia badań w dziedzinie międzykulturowej. Kulturowe wymiary Hofstede stały się podstawą przedstawionych badań, a także tekstów literackich pierwotnie napisanych $\mathrm{w}$ języku angielskim, których fabuła rozgrywa się w wybranych krajach muzułmańskich (Iran i Afganistan).
\end{abstract}

Słowa kluczowe: międzykulturowość; wymiary kulturowe; literatura; Wschód; Zachód

\begin{abstract}
The article explores intercultural differences between East and West throughout cultural dimensions and literature. Already existing sociological research is supplemented with literary one, thus creating a modern way of performing research in the field of interculture. Hofstede's cultural dimensions became the basis of the presented research as well as literary texts originally written in English, whose plot is set in the selected Muslim countries (Iran and Afghanistan).
\end{abstract}

Keywords: interculture; cultural dimensions; literature; East; West 


\section{INTRODUCTION}

The process of globalization forces us to examine and explore culture of other countries. In the past, we lived in the environment with people who were very similar to each other in their way of life, dressing, eating and speaking the same language. Today, this model does not exist anymore in society. At present, we live in neighbourhood with people who adhere to different values, behave according to different standards and even speak different languages. Intercultural communication serves to overcome these differences in multicultural society. Slovak culturologist Jana Pecníková (2017: 92) claims that "cultural education and teaching languages should prepare people for intercultural communication". The development of intercultural competences is the basis for effective business cooperation and harmonious coexistence. Thus, the aim of this article is to explore, present and clarify the cultural differences between East (represented by Muslim countries, specifically Iran and Afghanistan) and West (represented by Slovakia and the USA) as nowadays we encounter the "otherness" more often due to the migration of people from so-called Eastern cultures. There are situations in contact with these foreigners that can be characterized as a conflict, confrontation or conflict of identities. These processes often manifest disinterest, refusal and discrimination. Although migration is not a historically new or unique phenomenon, the current refugee crisis (beginning in 2015) has affected almost all spheres of postmodern society, increasing the importance of intercultural communication and competence.

One of the basic researches in the field of interculture, which became the basis of presented findings, is the comparative research of 50 countries, carried out by Dutch sociologist Geert Hofstede, from 1967 to 1973 (www.hofstede-insights.com/models/national-culture). Later, 23 other countries were included into the research. Hofstede chose IBM branches for his quantitative research. He focused on cultural differences in employees' behavior and took into account the level of national culture, the level of culture associated with a certain ethnic, religion or language, the level of culture associated with a generation, gender, class and organizational culture (Dolinská 2016: 53). He considers culture to be a collective phenomenon because people living in a common social environment share it. Culture consists of unwritten rules of the social game. "It is collective programming of the mind that distinguishes the members of one group or category of people from others" (Hofstede, Hofstede and Minkov 2010: 6). According to him, culture is learned, not innate and derived from the social environment. 


\section{NOVELS FROM THE EASTERN CULTURES - THE RESEARCH SAMPLE}

Culture consists of various elements of material and spiritual nature. One of the most important parts of culture is literature. Literature represents the culture of a particular nation and spreads it as well. That is why we based the intercultural research not only on sociological basis but also on a corpus made up of a set of novels dealing with the topic of life in Muslim countries. The first group of novels is from the Iranian environment, which consists of the unintentional tetralogy of novels by three authors, Betty Mahmoody, the author of the novels Not Without my Daughter (1987) and For the Love of a Child (1992), her daughter Mahtob ${ }^{1}$, the author of a novel My Name is Mahtob (2013), and Moody $^{2}$ - Mahmoody's ex-husband and Mahtob's father, the author of Lost Without my Daughter (2013). This mixed trio controversially responds to the clash of two different cultures that have affected their lives.

The second, contrasting view of the issue of the "otherness" of culture is represented by an "insider", the Afghan-American writer Khaled Hosseini, author of the novel A Thousand Splendid Suns (2007), which tells the story of two women (Mariam and Laila), both generationally and socially different, whose lives are linked by marriage to one man and a war that has forced millions of Afghans to flee abroad. Violence, fear and the unfair position of women, but also faith, hope, protection of families and national values are portrayed in the novel. A Thousand Splendid Suns describes the development of Afghan society (from the 1960 s to the beginning of the millennium) and the impact of consolidating Islam on the lives of people in that country. Moreover, it is a touching story of family, love, friendship and a power of sacrifice.

Hosseini is currently one of the best-known and most popular authors that write about Afghanistan. In 2008, he became the most successful author in the world. He defeated bestselling writers such as Joanne K. Rowling, Stephenie Meyer and Paulo Coelho (www.martinus.sk/?uItem=60977\#description). By writing about life in Afghanistan, he seeks to bring Eastern culture closer to Western readers. Hosseini hopes that readers emotionally identify with the fate of people in Afghanistan (www.bookbrowse.com/author_interviews/full/ index.cfm/author_number/900/khaled-hosseini). His novels are full of pain and suffering that Afghans have been facing for a long time.

\footnotetext{
1 As the surnames of mother and daughter are the same, we use only the first name, Mahtob, to distinguish between them.

2 As the surnames of Betty Mahmoody and her ex-husband are the same, we use only the first name, Moody, to distinguish between them.
} 


\section{NOVELS' SELECTION CRITERIA}

The selection of the research sample was preceded by an analysis of stories from the Muslim environment. The main criteria for selecting particular novels by the Mahmoody family and Khaled Hosseini were triple. The first one was that literary texts were originally written in English and translated into the Slovak language, thus, the Slovak readers became the target readers. In the last three decades, an increasing number of women's dramatic stories, who have experienced living in a Muslim country as well as having a romantic relationship with a Muslim, have recently appeared in the Slovak book market, which encourages readers to explore a different culture. For an illustration, the novel Not Without My Daughter belongs to the first ones (depicting the life in a Muslim country) that were published after the Velvet Revolution (1989) in Slovakia. This novel can be read as an exciting bestseller about a brave woman and mother, but more importantly, it has an undeniable testimony about the tensions between "Muslim" and "Western" culture.

Both examined Muslim cultures are part of the Orient, which, according to Edward W. Said (2003: 52), is largely the world of text through books and manuscripts. Thus, the second criterion become the plot setting in selected Muslim countries. Finally, in order to achieve the highest possible validity of the submitted research, we included only those authors who had had their personal experience with life in both a Muslim country and the USA, what made them valuable and reliable sources of intercultural differences.

The research of the intercultural differences is based on the Hofstede's findings. Despite the objections to his research that many cultural and national aspects are simplified (Pecníková 2013), Hofstede's findings became the starting point for the research needs. We completed his research with our own findings based on literary text analysis, thus, connecting sociological research with literary one.

\section{COMPARISON AND CHARACTERISTICS OF SELECTED COUNTRIES BASED ON HOFSTEDE'S CULTURAL DIMENSIONS}

Comparison of cultures is possible when comparing the emphasis placed on individual elements of human behavior within a particular culture. These basic tendencies of the members of the society are called cultural dimensions and cannot infiltrate to each other (Poliak 2015: 23). According to Hofstede, dimensions are aspects of culture that can be measured in relation to other cultures (Hofstede, Hofstede and Minkov 2010: 31). These cultural dimensions 
can be combined to create a typology of national culture dimensions. In addition to Hofstede, the typology of cultural dimensions was also attempted by Fons Trompenaars in cooperation with Charles Hampden-Turner. Models of cultural dimensions are based on bipolar scales, which in extreme positions have the extreme form of a single feature (Poliak 2015: 23).

The presented article is based on the findings of Hofstede as well as the American professor Charles A. Rarick, who together with his colleagues, explored the cultural dimensions in Afghanistan. Hofstede did not include it in his initial or further research, as IBM has not have a branch in Afghanistan yet. There is still insufficient empirically based literature on the cultural classification of this country. Rarick's research team examined cultural differences on a sample of 46 Afghan students studying business and economics at Kabul University. The sample consisted of 37 male and 9 female respondents, who were mainly urban residents aged 19 to 23 years and represented an elite part of Afghan society. We assume that one reason for choosing this research sample is the fact that a relatively high percentage of young people live in Afghanistan. In accordance to the data from the US Health Organization, approximately $46 \%$ of people under the age of 15 form the Afghan population, much more than in the surrounding countries of the region (Zaher 2014: 55). The results of Rarick's research were summarized in a scientific study Afghanistan's Younger, Elite and Educated Population: A Cultural Assessment and Possible Implications for the Economic and Political Future of the Country (2013). We have followed up on the findings of Hofstede and Rarick's research, which play a key role in exploring the "otherness" of Muslim cultures. We have supplemented them with our own findings from the analysis of the literary works, which are considered to be a relevant source of intercultural differences.

\section{HOFSTEDE'S CULTURAL DIMENSIONS}

Cultural dimensions are an important tool in confronting cultures, as they point to the context of the culture, which an individual comes from. Currently, Hofstede provides us with the opportunity to compare cultures in the so-called 6-D model, which describes in details the ways, manifestations and standards of behavior in particular cultures. This model includes the following cultural dimensions that are contained in Figure 1:

1. Power Distance expresses people's relationship to a certain authority. The high power distance index reflects that members of society accept and expect an uneven distribution of power in society. Conversely, a low degree of power distance means equal relationships in society. 
2. Masculinity vs Femininity expresses the distribution of male and female roles in society. In masculine societies, assertiveness and toughness are preferred in connection to material success, while in feminine societies, modesty and interest in quality of life are preferred. Masculinity is typical of cultures, in which gender roles are strictly differentiated, femininity - of cultures where gender roles overlap.

3. Individualism vs Collectivism - individualist societies do not usually feel a great commitment to the family, while collectivist societies form cohesive groups. This dimension correlates with the amount of gross domestic product per person. The higher the standard of living in a country, the higher the level of individualism of the members of the community.

4. Uncertainty Avoid ance reflects how people feel threatened by uncertainty and unknown impulses and situations.

5. Pragmatism expresses how people cope with the fact that much of what is happening around them cannot be explained. In normative societies, most people have a strong desire, even the need to have explained as much as possible. They have a keen interest in establishing absolute truth and personal stability. In such a society, there is a clear respect for social conventions and traditions, a focus on achieving rapid goals and a low tendency to save for the future. In a pragmatic society, most people do not need to have everything explained, believing that it is impossible to fully understand the complexity of life. The challenge is not to know the truth, but to live an honest and decent life. Pragmatic societies believe that truth largely depends on the particular situation, context and time. In addition to this, these societies are able to accept inconsistencies, adapt to circumstances and conditions, postpone, save, invest and persist in achieving results (Hofstede, Hofstede and Minkov 2010: 275).

6. Indulgence means in particular general enjoyment of life, leisure, entertainment, holidays, etc. The value of the indulgence index expresses how a certain society is able to renounce them. Societies that suppress the satisfaction of their needs do so by adhering to strict social standards (ibidem: 281). 


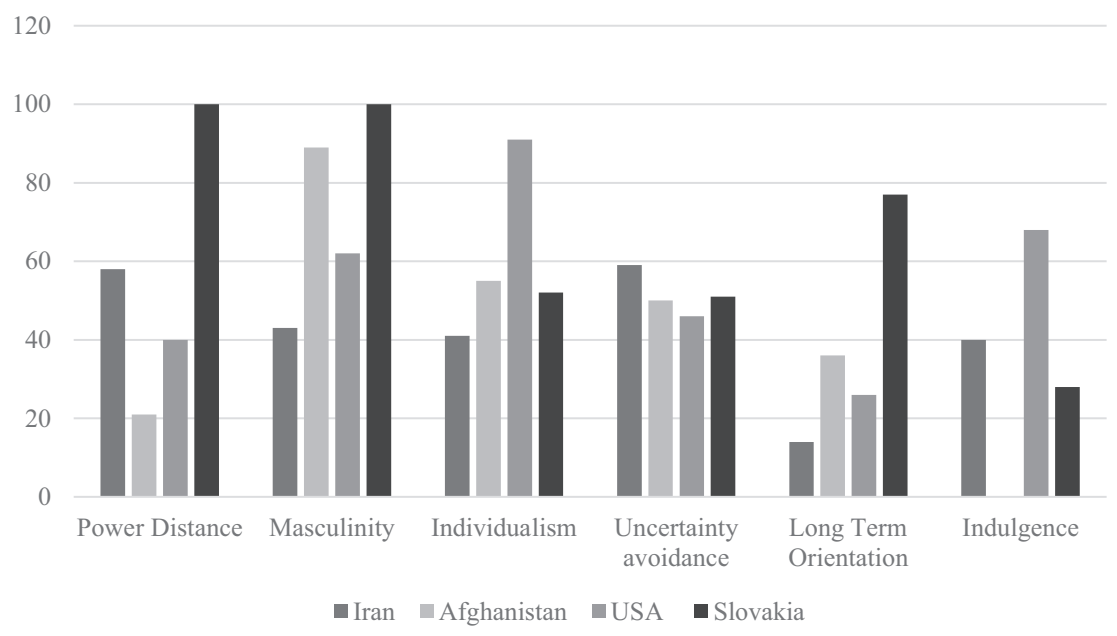

Figure 1. Hofstede's cultural dimensions

Source: (Rarick et al. 2013; Hofstede, Hofstede and Minkov 2010).

\section{POWER DISTANCE}

The most significant score in power distance (100), out of the compared countries, achieved Slovakia. Generally, Slovaks accept authorities and superiors, rarely express their opinion and do not tend to oppose them (Poliak 2015: 47). This behavior is the result of a socialist past. After 1989, there were changes not only of the regime but also to people's minds and behavior. The younger generation is more ambitious and more "brave" towards their superiors. They have experience with studying abroad, travel a lot more and thus get to know other cultures. They work in international companies where a performance-oriented corporate policy is applied, employees are involved in managing the company and do not have to worry about expressing their opinion.

Similarly, in Iran, the regime has also changed, but in a different way than in Slovakia. Iranian society is built on a different basis. Respect for the elderly people is deeply rooted in the culture of this country. People accept the hierarchical order of the society in which everyone has his/her position. Mahtob also confirmed "the hierarchical nature of Persian society" (Mahmoody 2015), in which her father outranked other members of the family on some "invisible family totem pole" (Mahmoody 2015). Both countries, Slovakia and Iran, are characterized by inequality in society. Centralization is popular, and subordinates expect to be told what to do. 
On the contrary, the situation in America is different. Supervisors are achievable and available; managers can rely on the expertise of individuals and their teams (Poliak 2015: 51). Employees are expected to take initiative, creativity and independence. Equal opportunities, hard work and the associated promotion are the foundation of American society. Mahmoody acknowledged the above-mentioned possibilities to live a better life in America. She made herself from a clerk to head of department. By marrying to an Iranian anesthesiologist, she got into the so-called higher society. Paradoxically, the traumatic events of her stay in Iran eventually brought her fame, recognition and money. Her ex-husband Moody personifies the fulfillment of "American dream". As the author stated, he got to America on a student visa, where he obtained a bachelor's degree and taught mathematics in a high school for several years. He was interested in mechanical engineering, so he went to school again. The company he worked for was a subcontractor for NASA and participated in the Apollo project. When he was thirty years old, he decided to become a doctor. This profession is highly valued in Iran. Both his parents were doctors. However, because of his age, he was not accepted by university. Finally, he graduated as a chiropractor. He wanted to become an anesthesiologist, because of the vision of high income, thus, confirming how Americanized he was. He obtained a green card that allowed him to practice the profession of doctor in the USA and was a good prerequisite for obtaining US citizenship. Moody's life in America was calm until the outbreak of the Iranian revolution.

For nearly two decades he did adopt many of the practices of Western society and, unlike so many of his counterparts, divorced himself from politics. He found a world far different from his childhood, one that offered affluence, culture, and basic human dignity that surpassed anything available in Iranian society. Moody truly wanted to be a westerner (Mahmoody and Hoffer 1989: 68).

American society is famous for declaring opportunities for everyone, regardless of gender, race, religion or ethnicity. Hosseini also expressed himself as a good example of a fulfilled American dream. He claims he came to America almost without money, with a suitcase of clothes and family (www.achievement.org/achiever/ khaled-hosseini/\#interview). Before publishing books, he had a successful doctor career. Currently, he is one of the world's most respected authors.

The power distance index reached the lowest level in Afghanistan. Professor Rarick and his team compared neighboring countries in the region, such as Iran, Iraq, Pakistan, Saudi Arabia and the United Arab Emirates, which are characterized by a high level of power distance. It is necessary to remind that respondents were of so-called elite part of Afghan society. The research sample does not represent the overall Afghan population and a broader view of Afghan society, but it represents the cultural values of the educated elite, which are useful 
for developing and improving Afghanistan. It is a country once ruled by a king, who gave extraordinary great power and autonomy to the tribes (Rarick et al. 2013). Although they are located in more remote parts of the country, their laws influence formation of national culture. In addition to the influence of individual tribes on national culture, we can also speak about different values in cities and rural areas. Hosseini (2008: 114) believes in better future for Afghanistan that young educated elite can bring because "a society has no change of success if its women are uneducated". The author expressed hope for Afghanistan in the form of young and educated women.

\section{MASCULINITY VS FEMININITY}

A high score in this dimension suggests that a society is driven by competition, competitiveness and success. Following this model, people are brought up this way at schools and later they transfer acquired knowledge into the skills in their working life. From the graph, we can see that except Iran, the other compared countries are masculine. For Americans, trying to achieve the best result is natural. The winner is inspiring for others, they do not envy him/her, but on the contrary, it is motivation for them to perform better.

Slovakia again achieved the highest score. The motives for achieving success are mainly related to better financial rewards. Slovaks want to take care of their families, so they spend more time at work. In Slovak society material values have become more important than interpersonal relationships. This change in people's minds was also caused by the previous regime, in which people felt material limits on the goods and services currently available. At present, cars, houses, branded clothes and exotic holidays are the measure of success, status and higher standard of living (Poliak 2015: 47).

As in the case of Slovakia, Afghans long for a better life, as evidenced by the high masculinity index. Hosseini believes in restoring the country and sees a better future for Afghanistan in education, which is again available to women:

Girls are going back to school and learning again. Women are returning to the workplace. They wear the Burqa if they want to but they don't have to. Once again they can move about without the presence of a male adult companion, wear makeup, listen to music and so on. (www.bookbrowse.com/author_interviews/ full/index.cfm/author_number/900/khaled-hosseini)

The situation in Afghanistan is much better today, but there is still room for improvement. Although Afghanistan has reached a high masculinity index, it 
cannot be considered identical to the US and Slovakia. "Having a good time" in the Western world does not mean the same as in Orient. The quality of life in Orient is expressed by the spirituality.

In Iran, relationships and family are more important than material benefits, which is also reflected in the outcome of Hofstede's research. Iran can be considered a feminine society, and it should be noted that the research was conducted during the last Shah's reign. As the regime has been changed in the country, we consider it necessary to perform a new research to find out if the values in the Hofstede taxonomy would change. Mahmoody, who lived in Iran at the time of the Khomeini's reign, described the life in Iranian families, in which male and female roles were divided that is typical for a masculine society. Women cooked and served food. However, baking bread was a man's duty. If a war broke out, this task was taken over by women. The division of roles relates not only to tasks but also to the position and status in the society. Mahtob remembered how children used to sit in a place other than adults, which she, despite Iranian customs, ignored. Men ate first, then women and children last. Tea was served in the same order, which is the opposite of Western rules. Feminine societies are characterized by modesty, work is a source of living, assistance to others and solidarity are highly valued. The status is not publicly presented, which is in contradiction to highlighting Moody's status in society as a doctor, either by himself, his wife and even his daughter. In addition, all three emphasised the fact that he came from a respected Iranian family. Another characteristic feature of feminine society is that conflicts are settled by compromise, and the parties strive for consensus, which is again in contrast to current political development. The Polish journalist Ryszard Kapuściński (1985) also wrote about Iranian rivalry, about their game "whose I is superior" that is a sign of masculine society too.

\section{INDIVIDUALISM VS COLLECTIVISM}

This dimension reflects the level of interdependence that society maintains among its members. In individualistic societies, people only care about themselves and their close relatives. On the contrary, in collective societies, people come together in groups where they are protected in exchange for loyalty.

Out of compared countries, the USA is the strongest individualistic society, in which personal responsibility, initiative and autonomy are of great importance. In working life, they are expected to express their individual opinion, in private life they apply the principle of non-interference in others' affairs.

Opposite to the USA is Iran, with its collective society, as reflected in family ties. For example, the family meets on Friday, which is a Muslim holiday. 
Mahmoody described how "Moody's relatives came in droves, crowding into the hall for lunch or dinner" (Mahmoody and Hoffer 1989: 35). It is common in Iran to live in a multi-generation house, relatives live very close to each other. In working life, collectivism manifests itself in favor of cooperation with family members. Mahmoody mentioned that members of the Moody family had a joint cosmetics business.

Compared to Iran, in Afghanistan there is a genuinely individualistic society, which we can attribute to the ambitions of a representative sample of young people. A change from collectivism to individualism also occurred in Slovakia. Young people are not afraid to travel for work or study, gradually breaking family ties.

\section{UNCERTAINTY AVOIDANCE}

Avoiding uncertainty means whether we should control the future or let it evolve itself. This ambiguity brings with it the anxiety and concern that cultures solve differently. The level to which members of a particular culture feel threatened by ambiguous or unknown situations is reflected in the scores they have achieved in this dimension. Slovakia (51 points) and Afghanistan (50 points) scored similarly, in the middle of the scale, which does not indicate unequivocal preferences. The avoidance of uncertainty has a different form in Afghanistan than in Slovakia. In Slovakia, we talk about caution and risk-taking in the business sector, however, in Afghanistan we assume avoiding any uncertainty and risks in daily lives. The probability of avoiding uncertainty is higher in Iran than in Afghanistan or Slovakia. Iranians prefer to maintain rigid codes of faith and behavior that arise from peoples' emotional need to adhere to the rules. They accept innovation with difficulty and respond more sensitively to change. The most flexible are Americans. They accept challenges, new ideas and innovations. They are willing to try something new or different. Americans tend to be more tolerant of someone else's views.

\section{PRAGMATISM}

Pragmatism describes how an individual society maintains ties with its own past, while accepting the challenges of the present and the future. Normative societies that are at a low level in this dimension prefer to preserve traditions and suspect social change. On the other hand, pragmatic societies are able to adapt more quickly to change, people look to the future, save and are relentless in achieving their goals. Education is seen as a tool to prepare for the future.

According to Hofstede's research, Slovakia is a pragmatic country in which most people believe that truth depends on the specific situation, context and 
time (www.hofstede-insights.com/country-comparison/slovakia). American culture can be considered normative, as its members like to verify facts and analyze the information they gathered. Americans respect their own traditions, symbols and values. In the novel For the Love of a Child, Mahmoody described how the American flag became a symbol of their liberation (Mahmoody and Dunchock 1991: 3), the national anthem gained new meaning for her (ibidem: 14), and when she first saw the Statue of Liberty after returning from Iran, she was able to appreciate again what it symbolized (ibidem: 15). Afghanistan and Iran are also normative societies. Mahmoody depicted how the Moody's family sacrificed sheep in their honor, a Persian tradition of showing respect to those who have just returned home. Guests are expected to cross the pool of blood and enter the house. Mahmoody considered this a "stupid thing" and "crazy tradition" (Mahmoody and Hoffer 1989: 24), showing disrespect for her husband's culture. Mahtob also remembered this situation negatively: "in my father's culture, this was an extremely high honor, but to me it was traumatic" (Mahmoody 2015). It is necessary to remind that at that time she was only four years old and grew up in a different culture.

Hosseini also writes about many Afghan customs and traditions. From his novel we learn about a wedding ceremony called nikka (Hosseini 2008: 49). Green is considered a suitable color for a wedding gown. Mariam wore "a long-sleeved, dark green dress to wear over white cotton trousers [...] green hijab and a pair of matching sandals" (ibidem: 51). The ceremony took place in a room with a long brown table in the middle of which lay the Qur'an, a green veil, a mirror and a bowl of almond confectionery. She was instructed to wait until the mulla asked her three times. The point of this is that a man asks a woman, not the other way around. In the mirror, for the first time Mariam saw the face of her husband, who was much older from her. In the Oriental countries, marriages are often concluded between partners who are of significant age difference. Marriages are negotiated by the parents or other authorized persons.

\section{INDULGENCE}

This dimension defined the extent to which people try to control their desires and impulses. Relatively weak control means a tendency to enjoy life, while strong control means restraint. Based on this, we divide cultures into "indulgent" and "restraint". According to Hofstede's findings, Slovakia ranks among the countries and cultures characterized by self-control and modesty (Poliak 2015: 48). It is necessary to remind that there have been changes in this dimension, as Slovaks, especially the younger generation, decide how they spend their free 
time and increasingly emphasize the quality of life. The United States is one of the countries where work and social life are very important. However, this does not exclude the room for efficient use of non-working time. In contrast to Western countries, the Orient is characterized by restraint and asceticism. We assume that the relationship to enjoyment in Afghanistan is similar to that in Iran. Professor Rarick has not explored this dimension, but we learn from Hosseini that during Ramadan, people renounced pleasures: "Mariam saw no smokers on the streets, no cups of tea steaming from window ledges. And at iftar, when the sun dipped in the west [...], the city broke its fast [...], with bread and a date [...]" (Hosseini 2008: 77).

Generally, drinking alcohol is forbidden in Muslim countries: "the Holy Koran forbids sharab. Because it always falls on the sober to pay for the sins of the drunk" (ibidem: 222). Mahmoody also mentioned the ban on alcohol. Moody was a Muslim, however, he "no longer practiced the extreme form of Islam under which he had been raised. Although he disdained pork, he enjoyed his glass of liquor. Only occasionally did he take out his prayer mat and perform his religious duties" (Mahmoody and Hoffer 1989: 72).

At home in America, everything was fine initially, but when the revolution broke out in Iran, the situation changed at home. Moody began to pray with piety she had never experienced before. He also threw away all the alcohol supplies they had at home. The relationship to his native land, roots, and habits of his ancestors was so powerful, even remotely, that he changed his way of life.

\section{CONCLUSIONS}

Each of the countries surveyed has its own social and cultural system, which we have examined throughout Hofstede's cultural dimensions. We presented the basic characteristics of the selected cultures, which we compared and supplemented with our own findings from the analysis of literary works. Umberto Eco and Jean-Claude Carrière (2010) wrote that "the importance of books is that they are the only media that remain comprehensible for centuries". In addition, they offer insight into culture and the diversity of cultural phenomena.

Betty Mahmoody is rather negative about the Iranian culture and its traditions, however, she provides the readers with detailed description of intercultural differences. On the other hand, Khaled Hosseini is attempting to make an objective representation of reality. As an Afghan, he would like readers "to walk away with a sense of empathy for Afghans, and more specifically for Afghan women, on whom the effects of war and extremism have been devastating" (www.bookbrowse.com/author_interviews/full/index.cfm/author_number/900/ 
khaled-hosseini). To conclude, literary works can be considered a relevant source of intercultural differences, and authors of literary works can adequately convey not only the way of life in a different country but also the thinking of its people. Reading books enriches our minds and souls, helps develop and improve our intercultural awareness and build relations with others based on accepting differences, but not in the cost of suppressing own cultural values and identity.

\section{REFERENCES}

An interview with Khaled Hosseini. In: BookBrowse. Retrieved from: www.bookbrowse. com/author_interviews/full/index.cfm/author_number/900/khaled-hosseini [access: 28.12.2019].

Country comparison. Slovakia. Retrieved from: www.hofstede-insights.com/country-comparison/slovakia [access: 9.05.2019].

Dolinská, V. (2016). Akulturačné štúdie pre ekonómov. Kultúrne odlišnosti medzinárodného pracovného prostredia. Bratislava: Wolters Kluwer.

Eco, U., Carrièr, J.-C. (2010). Knih se jen tak nezbavíme. Praha: Argo.

Hofstede, G., Hofstede, G.J., Minkov, M. (2010). Cultures and Organizations. Software of the Mind. Intercultural Cooperation and Its Importance for Survival. New York: McGraw-Hill.

Hosseini, K. (2008). A Thousand Splendid Suns. London: Bloomsbury Publishing.

Kapuściński, R. (1985). Shah of Shahs. Retrieved from: https://books.google.sk/ books?id=IwyuRdBtLMYC\&pg=PT110\&hl=sk\&source=gbs_toc_r\&cad $=3 \# \mathrm{v}=0$ nepage $\& \mathrm{q}=$ game $\& \mathrm{f}=$ false [access: 28.12 .2019$]$.

Khaled Hosseini, M.D. - Academy of Achievement. Retrieved from: www.achievement. org/achiever/khaled-hosseini/\#interview [access: 9.04.2019].

Mahmoody, B., Hoffer, W. (1989). Not Without My Daughter. London: Transworld Publishers.

Mahmoody, B., Dunchock, A. (1993). For the Love of a Child. Sydney: Pan Macmillan Publishers Australia.

Mahmoody, M. (2015). My Name Is Mahtob. London: Little, Brown Book Group.

Mahmoody, S. (2013). Lost Without My Daughter. London: Thistle Publishing.

National Culture. Retrieved from: www.hofstede-insights.com/models/national-culture/ [access: 9.05.2019].

Pecníková, J. (2013). Sociologické a kultúrne aspekty interkultúrnej komunikácie v kontexte francúzskej kultúrnej identity na základe vybraných literárnych diel. In: Jazyk a kultúra. roč. 4. č́slo 16. Prešov: Filozofická fakulta Prešovskej Univerzity v Prešove. Retrieved from: www.ff.unipo.sk/jak/cislo16.html [access: 28.12.2019].

Pecníková, J. (2017). Rozvoj klúčových kompetencií v interkultúrnej komunikácii. In: Cudzie jazyky v premenách času VII. Recenzovaný zborník príspevkov z medzinárodnej vedeckej konferencie konanej dňa 11.11.2016 na Fakulte cudzích jazykov Ekonomickej univerzity v Bratislave (pp. 88-92). Bratislava: Ekonóm. 
Pobrane z czasopisma Annales N - Educatio Nova http://educatio.annales.umcs.pl Data: 26/04/2023 12:50:43

Poliak, P. (2015). Interkultúrne rozdiely v manažmente organizácií. Banská Bystrica: Belianum.

Rarick, Ch., Winter, G., Falk, G., Nickerson, I., Barczyk, C. (2013). Afghanistan's Younger, Elite and Educated Population: A Cultural Assessment and Possible Implications for the Economic and Political Future of the Country. Global Journal of Business Research, vol. 13(4). Retrieved from: https://journalofbusiness.org/index.php/ GJMBR/article/view/937/848 [access: 9.02.2019].

Said, E.W. (2003). Orientalism. London: Penguin Books.

Tisíc žiarivých slnk. In: Martinus. Retrieved from: www.martinus.sk/?uItem=60977\#description [access: 4.12.2019].

Zaher, Z.J. (2014). Afganistan. História. Boje. Prežitie. Bratislava: ZAHER International Trade. 